
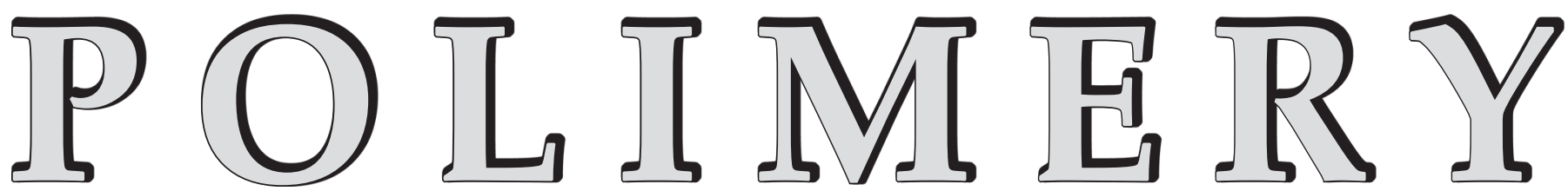

\title{
Polimeryzacja aniliny w środowisku stałego pola magnetycznego
}

\author{
Ewa Miękośl1), *) (ORCID ID: 0000-0002-1286-1436), Bronisław Samujło ${ }^{2)}$ (0000-0002-2200-8471), \\ Marek Zieliński ${ }^{1)}{ }^{(0000-0002-1577-5787), ~ D a r i u s z ~ S r o c z y n ́ s k i i^{1)}(0000-0003-1146-6714)}$
}

DOI: dx.doi.org/10.14314/polimery.2021.7.1

\begin{abstract}
Streszczenie: Badano wpływ stałego pola magnetycznego (SPM) na proces polimeryzacji polianiliny. Proces prowadzono na platynowych elektrodach płytkowych, nieizolowanych i izolowanych jednostronnie (z dwóch różnych stron) teflonem, o powierzchniach skierowanych równolegle do linii sił SPM. Stwierdzono, że właściwości magnetyczne cząstek biorących udział w procesie polimeryzacji elektrochemicznej oraz ich ładunek (+/-) mają istotny wpływ na oddziaływanie SPM na przebieg procesu. Zaproponowano mechanizm wpływu SPM na zachodzące reakcje elektrochemiczne, oparty na powstawaniu efektu magnetohydrodynamicznego (MHD), powodującego zmianę szybkości transportu reagujących substancji w kierunku elektrody.
\end{abstract}

Słowa kluczowe: anilina, polianilina, elektropolimeryzacja, stałe pole magnetyczne (SPM).

\section{Aniline polymerization in a constant magnetic field environment}

\begin{abstract}
The influence of the constant magnetic field (CMF) on the polymerization of polyaniline was investigated. The process was carried out on platinum plate electrodes, non-insulated and one-sided Teflon insulated (from two different sides), with surfaces directed parallel to the CMF line of force. It was found that the magnetic properties of the particles involved in the electrochemical polymerization process and their charge (+/-) have a significant impact on the influence of the CMF on the course of the process. The mechanism of the influence of CMF on the studied electrochemical reactions was proposed, based on the formation of the magnetohydrodynamic effect (MHD), causing a change in the rate of transport of the reacting substances towards the electrode.
\end{abstract}

Keywords: aniline, polyaniline, electropolymerization, constant magnetic field (CMF).

W stałym polu magnetycznym (SPM) prowadzono polimeryzację polimerów, takich jak żywica epoksydowa lub kauczuk silikonowy [1] czy biopolimery [2]. Badano też wpływ SPM na zachodzące reakcje organiczne, np.

\footnotetext{
1) Katedra Chemii Nieorganicznej i Analitycznej, Wydział Chemii, Uniwersytet Łódzki, ul. Tamka 12, 91-403 Łódź.

2) Katedra Technologii i Przetwórstwa Tworzyw Polimerowych, Wydział Mechaniczny Politechniki Lubelskiej, ul. Nadbystrzycka 36, 20-618 Lublin.

*) Autor do korespondencji: ewa.miekos@chemia.uni.lodz.pl
}

utlenianie kwercetyny [3] lub nieorganiczne, np. elektrochemiczne osadzanie metali i stopów $[4,5]$.

Anilina to najprostsza amina aromatyczna. Aktywowany przez podstawnik pierścień aromatyczny ułatwia jej utlenianie i polimeryzację. Reaktywność atomu azotu determinuje najważniejsze właściwości chemiczne amin. Ze względu na obecność wolnej pary elektronowej mają one właściwości zasadowe i nukleofilowe. Anilina znajduje szerokie zastosowanie m.in. w produkcji barwników, leków czy przyspieszaczy wulkanizacji, a także metalicznych elektrod do superkondensatorów 
[6]. Innym przykładem jej zastosowania jest czujnik elektrodowy do szybkiego i niedrogiego wykrywania bakterii Escherichia coli O157 : H7 (wysoce zakaźny i potencjalnie śmiertelny patogen przenoszony przez żywność i wodę) [7], w którym wykorzystano metodę wiązania przeciwciało-antygen. Metoda ta polega na wbudowaniu przeciwciała do polianiliny za pomocą wiązania kowalencyjnego.

Elektropolimeryzację polianiliny prowadzono na różnych podłożach węglowych [8] o dużej powierzchni, w tym na włóknach węglowych i usieciowanym węglu szklistym. Ze względu na różną strukturę, podłoże miało silny wpływ na charakterystykę elektryczną i strukturę otrzymanych warstw polianiliny. Polimeryzację elektrochemiczną polianiliny badano za pomocą korelacyjnych pomiarów elektrochemicznych i spektroskopii UV-Vis [9]. Utlenianie monomeru zachodziło przy wysokim potencjale dodatnim $(0,9 \mathrm{~V}$ vs $\mathrm{Ag})$.

Polianilina (PANI) jest dobrze znanym polimerem, jednak prowadzone od lat 80 . XX wieku badania procesów elektrochemicznych polimerów przewodzących i elektrod modyfikowanych polimerami wciąż budzą zainteresowanie [10]. Polianilina $\mathrm{w}$ postaci utlenionej jest odporna na działanie tlenu, co jest szczególnie ważne $w$ jej zastosowaniach. Posiada również bardzo ciekawe właściwości użytkowe. PANI można otrzymywać metodami chemicznymi na drodze syntezy elektrochemicznej, a także w fazie gazowej z użyciem plazmy, jak również w układzie dwóch faz ciekłych (faza polarna to wodny roztwór chlorku żelaza(III) i kwas siarkowy o stężeniu $0,1 \mathrm{~mol} / \mathrm{dm}^{3}$, a fazą niepolarną jest roztwór aniliny $\mathrm{w}$ benzenie). PANI powstaje na granicy faz podczas przepływu prądu elektrycznego. W chemicznych metodach otrzymywania PANI stosuje się szereg utleniaczy, takich jak dwuchromian potasu, nadsiarczan amonu, pirosiarczan amonu, nadtlenek wodoru, azotan(V) ceru(IV) czy siarczan(VI) ceru(IV) [11, 12]. Utleniacze stosuje się $\mathrm{w}$ niedomiarze $\mathrm{w}$ stosunku do ilości aniliny (nadmiar powoduje degradację polimeru). Syntezę PANI prowadzi się przy użyciu roztworu aniliny $0,01-1 \mathrm{~mol} / \mathrm{dm}^{3}$, przy $\mathrm{pH}=0-2$, w środowisku kwasów nieorganicznych: $\mathrm{H}_{2} \mathrm{SO}_{4^{\prime}}$ $\mathrm{HCl}, \mathrm{HClO}_{4}$ lub $\mathrm{HNO}_{3}$ (powstawanie PANI jest widoczne przez granatowe zabarwienie roztworu i pojawienie się osadu). Polimeryzacja prowadzona jest w zakresie temperatury $0-80^{\circ} \mathrm{C}$. Opracowano również technologię otrzymywania PANI i jej przetwórstwa w mieszaninach z innymi polimerami [13]. Do polianiliny dodawano substancje ferromagnetyczne i ferroelektryczne, powodując zmiany we właściwościach polimeru. Stwierdzono, że PANI może być składnikiem lakierów i mieszanin pochłaniających promieniowanie mikrofalowe w zakresie pracy radaru.

W metodach elektrochemicznych polimeryzację aniliny prowadzi się na elektrodach metalowych, zwłaszcza platynowych. Metoda elektrochemiczna nie wymaga stosowania utleniacza, a przebieg procesu można kontrolować (potencjał, ładunek, natężenie prądu). Polimeryzację prowadzi się w temperaturze pokojowej. Aby otrzymać polimer przewodzący, roztwory muszą mieć odczyn kwaśny $(\mathrm{pH}<2)$, a ładunki dodatnie pojawiające się w polimerze na skutek jego częściowego utlenienia, muszą być kompensowane przez aniony elektrolitu podstawowego za pomocą tzw. domieszkowania polimeru (min. 10\%). W reakcji polimeryzacji biorą udział dwa elektrony na cząsteczkę aniliny (pomiary kulometryczne wskazują $\mathrm{n}=2,16-2,70)$. Nadmiar ładunku zużywany jest na utlenienie już utworzonej PANI. Elektropolimeryzacja aniliny polega na elektrochemicznej reakcji przeniesienia ładunku inicjującego reakcje chemiczne prowadzące do powstania PANI. Proces zachodzi w kilku etapach [14]:

$$
\begin{gathered}
\mathrm{C}_{6} \mathrm{H}_{5} \mathrm{NH}_{2} \stackrel{-e}{\rightarrow} \mathrm{C}_{6} \mathrm{H}_{5} \mathrm{NH}_{2}^{+} \\
2 \mathrm{C}_{6} \mathrm{H}_{5} \mathrm{NH}_{2}^{+} \rightarrow \mathrm{C}_{6} \mathrm{H}_{5} \mathrm{NH}-\mathrm{C}_{6} \mathrm{H}_{4} \mathrm{NH}_{2}+2 \mathrm{H}^{+} \\
\mathrm{C}_{6} \mathrm{H}_{5} \mathrm{NH}-\mathrm{C}_{6} \mathrm{H}_{4} \mathrm{NH} \stackrel{-e}{\rightarrow}\left[\mathrm{C}_{6} \mathrm{H}_{5} \mathrm{NH}-\mathrm{C}_{6} \mathrm{H}_{4} \mathrm{NH}_{2}\right]^{+} \\
\mathrm{C}_{6} \mathrm{H}_{5} \mathrm{NH}_{2}+\mathrm{C}_{6} \mathrm{H}_{5} \mathrm{NH}_{2}^{+} \rightarrow\left[\mathrm{C}_{6} \mathrm{H}_{5} \mathrm{NH}-\mathrm{C}_{6} \mathrm{H}_{4} \mathrm{NH}_{2}\right]^{+}
\end{gathered}
$$

i następnie tworzenie wyższych oligomerów i ich rodników kationowych (kationorodników).

Istnieje również koncepcja, że polimeryzacja aniliny zachodzi poprzez tworzenie kationu $\mathrm{C}_{6} \mathrm{H}_{5} \mathrm{NH}^{+}$, który reagując $\mathrm{z}$ aniliną tworzy układy fenazynowe - schemat $\mathrm{A}$ :<smiles></smiles>

Schemat A

Pierwszy etap utleniania aniliny prowadzi do powstania rodnika kationowego (w pierwszym cyklu woltamperogramu występuje tylko jeden pik anodowy przy wartości potencjału utleniania aniliny, wynoszącej ok. 1,2-1,3 V względem elektrody kalomelowej) - schemat B:

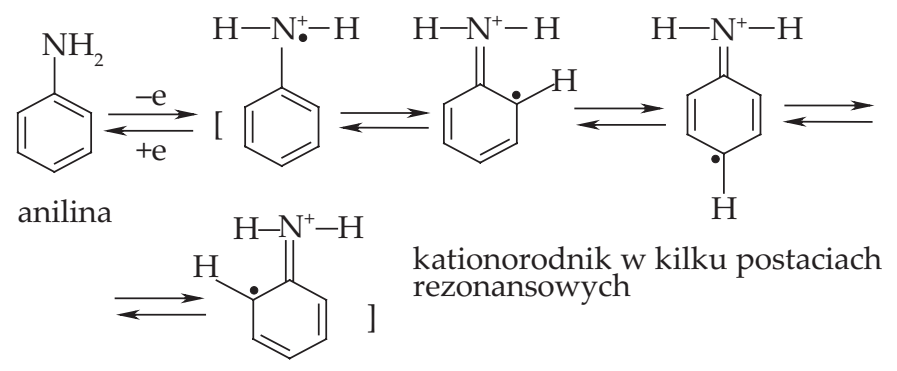

Schemat B 
W drugim etapie tworzy się dimer p-aminodwufenyloaminy (PADFA) - schemat C.<smiles>[NH+]=Cc1ccc([NH+]=C[InH])cc1</smiles>

kationorodnik

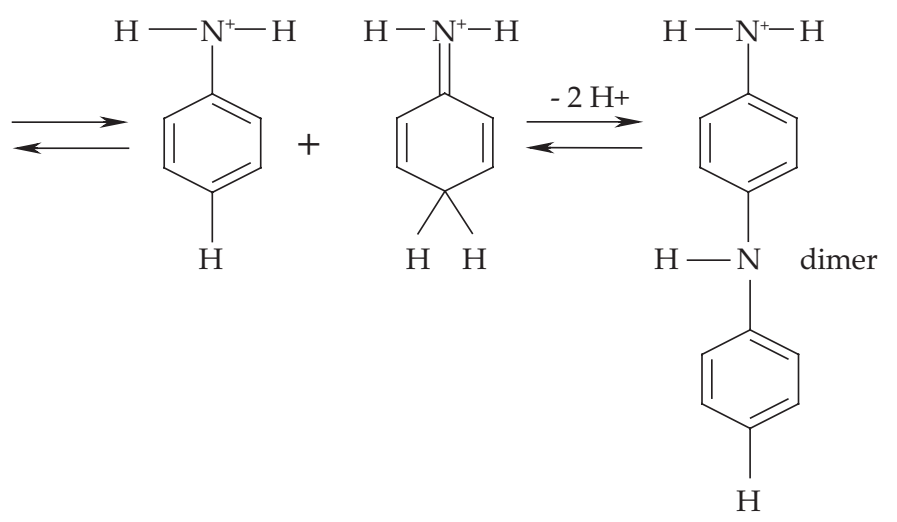

Schemat C

W środowisku kwaśnym (tak jak w prowadzonych przez nas badaniach) lub w acetonitrylu, oprócz PADFA powstaje niewielka ilość benzydyny. W trzecim etapie w wyniku reakcji utlenionej cząsteczki PADFA z rodnikiem kationowym aniliny tworzy się trimer, a następnie tetramer, aż do powstania polimeru o strukturze polianiliny - schemat D:

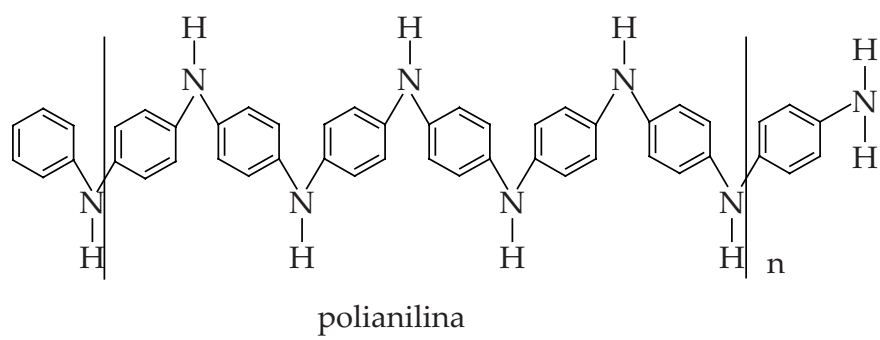

\section{Schemat D}

Wartości potencjału utleniania dimeru i oligomerów są znacznie niższe od wartości potencjału utleniania aniliny, dlatego w kolejnych cyklach woltamperometrycznych zaczynają tworzyć się piki utleniania PANI, które są bardziej intensywne i charakteryzują się wyższymi wartościami natężenia prądu. Powstające przy potencjale o wartości ok. 0,2 V (względem elektrody kalomelowej) piki tzw. pierwszego układu redoks, charakteryzują się wysokimi wartościami natężenia prądu i są wyraźnie widoczne. Dla pików odpowiadających utlenianiu układów fenazynowych, występujących przy potencjale o wartości ok. 0,7 V (względem elektrody kalomelowej), zarejestrowano niskie wartości natężenia prądu i piki są słabo widoczne $[15,16]$. Powstające przy potencjale o war- tości ok. $1 \mathrm{~V}$ (względem elektrody kalomelowej) piki tzw. drugiego układu redoks, charakteryzują się wysokimi wartościami natężenia prądu i są wyraźnie widoczne.

Celem niniejszej pracy było zbadanie wpływu stałego pola magnetycznego (SPM) na przebieg procesu polimeryzacji aniliny. Zaproponowano również mechanizm oddziaływania SPM na zachodzące reakcje elektrochemiczne.

\section{CZĘŚĆ DOŚWIADCZALNA}

\section{Materiały}

Roztworem podstawowym był kwas chlorowy(VII) o stężeniu $1 \mathrm{~mol} / \mathrm{dm}^{3}$, M=100,46 g/mol, c=71-73\%, $\mathrm{d}=1,7 \mathrm{~g} / \mathrm{cm}^{3}$, producent Searle Company Hopkin \& Williams (Anglia). Stosowano również wodny roztwór aniliny o stężeniu 0,1 $\mathrm{mol} / \mathrm{dm}^{3}, \mathrm{M}=93,13 \mathrm{~g} / \mathrm{mol}$, $\mathrm{d}=1,02 \mathrm{~g} / \mathrm{cm}^{3}$, producent P.P.H. Polskie Odczynniki Chemiczne S.A., Gliwice (Polska).

Proces polimeryzacji aniliny prowadzono na platynowych elektrodach płytkowych o powierzchni $2 \mathrm{~cm}^{2}$. Powierzchnie elektrod były nieizolowane $\mathrm{z}$ obu stron (wariant A) lub izolowane teflonem z jednej strony (wariant $\mathrm{B}$ - od góry, wariant C - od dołu) oraz skierowane równolegle do linii sił SPM. Elektrodą odniesienia była elektroda srebrowa. Stosowano SPM o różnej indukcji magnetycznej B, w zakresie 0-1500 mT (0-15000 Oe). Poniżej opisano stosowane warianty elektrod platynowych.

Wariant A - elektroda nieizolowana z obu stron

Wariant B - elektroda izolowana teflonem z jednej strony (od góry)

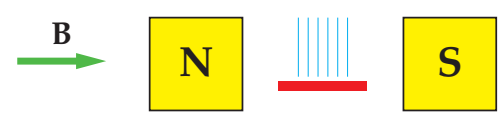

Wariant C - elektroda izolowana teflonem ze strony przeciwnej (od dołu).

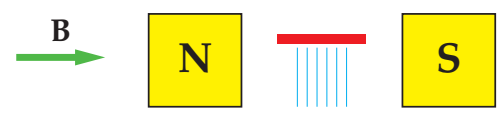

gdzie : B - wektor indukcji magnetycznej, równoległy do powierzchni platynowej elektrody płytkowej; N, S bieguny elektromagnesu.

\section{Metody}

Do badania wpływu stałego pola magnetycznego (SPM) na przebieg elektrochemicznego procesu otrzymywania polianiliny (PANI) stosowano metodę woltamperometrii cyklicznej. Metoda ta jest zalecana przez wielu autorów do badania kinetyki elektrodowej i procesów elektrodowych związków organicznych [17, 18]. Szybkość transportu składników w roztworze podczas procesu wynosiła $10^{-4}-10^{-3} \mathrm{~cm} / \mathrm{s}$ i mieściła się w zakresie dokładności stosowanej metody $\left(4,8 \cdot 10^{-4}-1,2 \cdot 10^{-1} \mathrm{~cm} / \mathrm{s}\right)$. 


\section{WYNIKI BADAŃ I ICH OMÓWIENIE}

Na rys. 1 przedstawiono krzywe woltamperometryczne dla serii wykonanych pomiarów. Obliczone stałe szybkości reakcji redoks wskazywały, że reakcje polimeryzacji aniliny były quasi-odwracalne [17].

$\mathrm{W}$ reakcji uwzględniono dwa układy redoks (oznaczone na rys. 1 jako I i II):

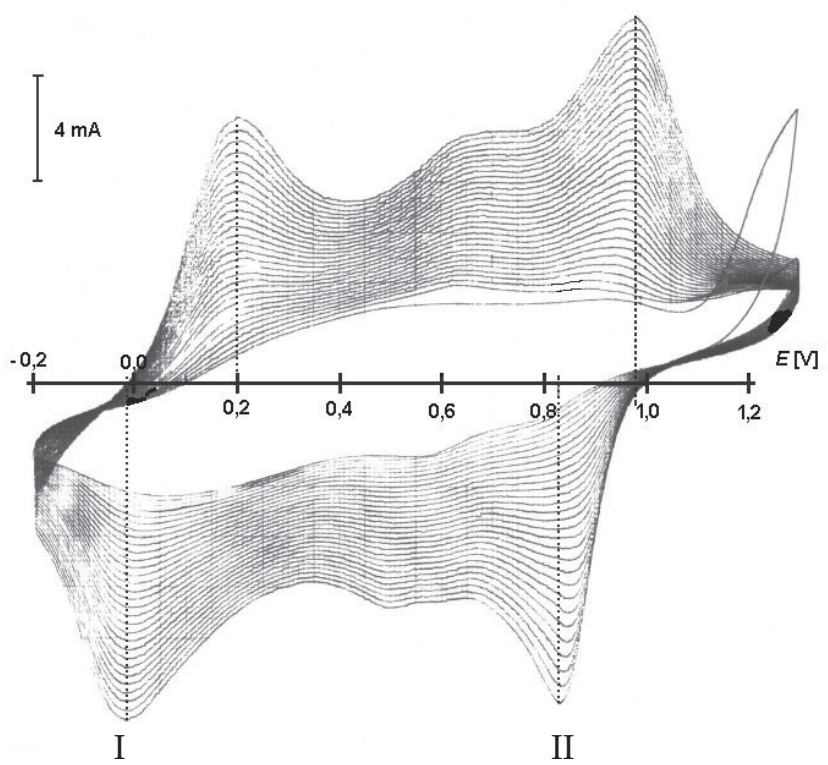

Rys. 1. Woltamperogram elektropolimeryzacji aniliny $\left(0,1 \mathrm{~mol} / \mathrm{dm}^{3}\right) \mathrm{w}$ roztworze kwasu chlorowego(VII) $1 \mathrm{~mol} / \mathrm{dm}^{3}$, na platynowej elektrodzie płytkowej, dla dwóch układów redoks I, II (30 cykli)

Fig. 1. Cyclic voltammogram of aniline $\left(0.1 \mathrm{~mol} / \mathrm{dm}^{3}\right)$ electropolymerization in $1 \mathrm{~mol} / \mathrm{dm}^{3}$ chloric acid(VII) solution, on a platinum plate electrode, for two redox systems - I, II ( 30 cycles)

$$
\begin{aligned}
& \mathrm{C}_{6} \mathrm{H}_{5} \mathrm{~N} \cdot \cdot \mathrm{H}_{2} \underset{+\mathrm{e} \text { (red.) }}{\stackrel{\text { e (utl.) }}{\rightleftarrows}}\left[\mathrm{C}_{6} \mathrm{H}_{5} \mathrm{~N}^{\bullet} \mathrm{H}_{2}\right]^{+} \\
& \text {anilina kationorodnik } \\
& \underset{\substack{\text { dimer } \\
\text { diamagnetyczny (-) }}}{\mathrm{C}_{6} \mathrm{H}_{5} \mathrm{NH}-\mathrm{C}_{6} \mathrm{H}_{4} \mathrm{~N} \cdot \cdot \mathrm{H}_{2} \underset{\text { +e(red.) }}{\stackrel{-\mathrm{e}(\mathrm{utl} .)}{\rightleftarrows}}}\left[\underset{\begin{array}{c}
\text { kationorodnik } \\
\text { paramagnetyczny (+) }
\end{array}}{\left.\mathrm{C}_{6} \mathrm{H}_{5} \mathrm{NH}-\mathrm{C}_{6} \mathrm{H}_{4} \mathrm{~N} \cdot \mathrm{H}_{2}\right]^{+}}\right.
\end{aligned}
$$

$\mathrm{Na}$ początku zbadano reakcję utleniania aniliny i dimeru oraz siły magnetohydrodynamiczne (MHD), które mogą powstać w wyniku działania SPM i pola elektrycznego. Na rys. 2. przedstawiono procentową zależność zmiany natężenia prądu anodowego od indukcji magnetycznej. Najwyższe wartości natężenia prądu anodowego uzyskano w obu układach dla wariantu C, ponieważ cząstki aniliny lub dimeru (diamagnetyczne) na skutek działania SPM i powstałych sił $\mathrm{F}_{\mathrm{B}}$ (pochodzących od SPM) wykonywały ruch obrotowy sprzyjający ruchowi cząstek aniliny lub dimeru w kierunku elektrody. Jony roztworu podstawowego (ujemne, diamagnetyczne) pod wpływem działania sił $\mathrm{F}_{\mathrm{B}}$ wykonywały

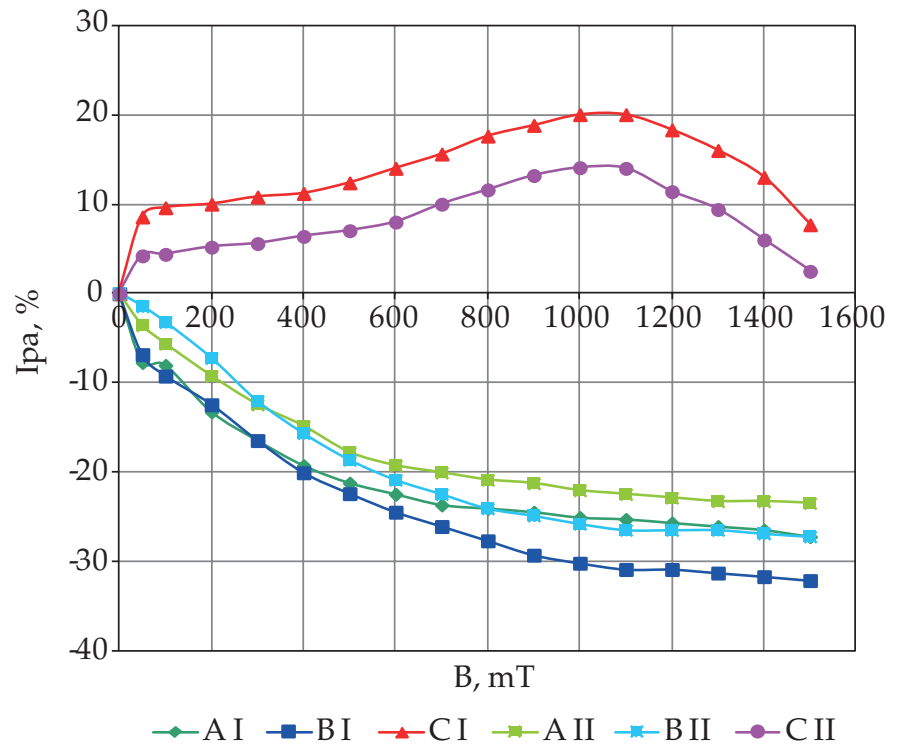

Rys. 2. Zależność zmiany natężenia prądu anodowego (Ipa) od indukcji magnetycznej (B) $\mathrm{w}$ reakcji polimeryzacji aniliny $\left(0,1 \mathrm{~mol} / \mathrm{dm}^{3}\right) \mathrm{w}$ roztworze kwasu chlorowego(VII) $1 \mathrm{~mol} / \mathrm{dm}^{3}$, na elektrodzie platynowej, odpowiednio dla dwóch etapów przenoszenia ładunku - I i II

Fig. 2. Dependence of the anode current (Ipa) change on the magnetic induction $(B)$ in the aniline $\left(0.1 \mathrm{~mol} / \mathrm{dm}^{3}\right)$ polymerization reaction in $1 \mathrm{~mol} / \mathrm{dm}^{3}$ chloric acid(VII) solution, on the platinum electrode, for two charge transfer stages - I and II, respectively

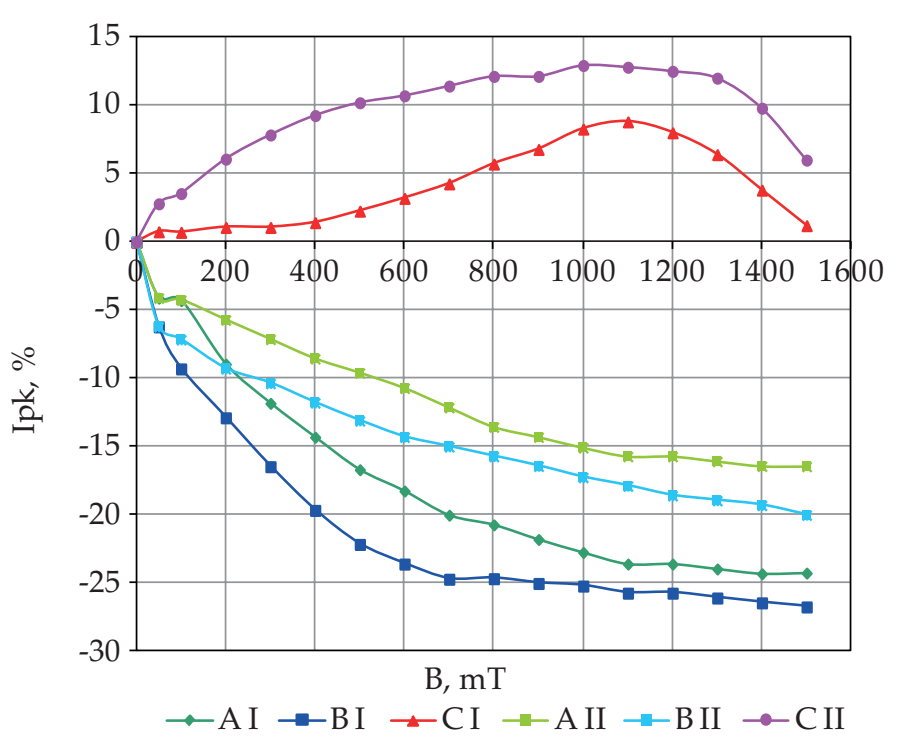

Rys. 3. Zależność zmiany natężenia prądu katodowego (Ipk) od indukcji magnetycznej (B) $\mathrm{w}$ reakcji polimeryzacji aniliny $\left(0,1 \mathrm{~mol} / \mathrm{dm}^{3}\right)$ w roztworze kwasu chlorowego(VII) $1 \mathrm{~mol} / \mathrm{dm}^{3}$, na elektrodzie platynowej, odpowiednio dla dwóch etapów przenoszenia ładunku - I i II

Fig. 3. Dependence of the cathode current (Ipk) change on the magnetic induction (B) in the aniline $\left(0.1 \mathrm{~mol} / \mathrm{dm}^{3}\right)$ polymerization reaction in $1 \mathrm{~mol} / \mathrm{dm}^{3}$ chloric acid(VII) solution, on the platinum electrode, for two charge transfer stages - I and II, respectively 


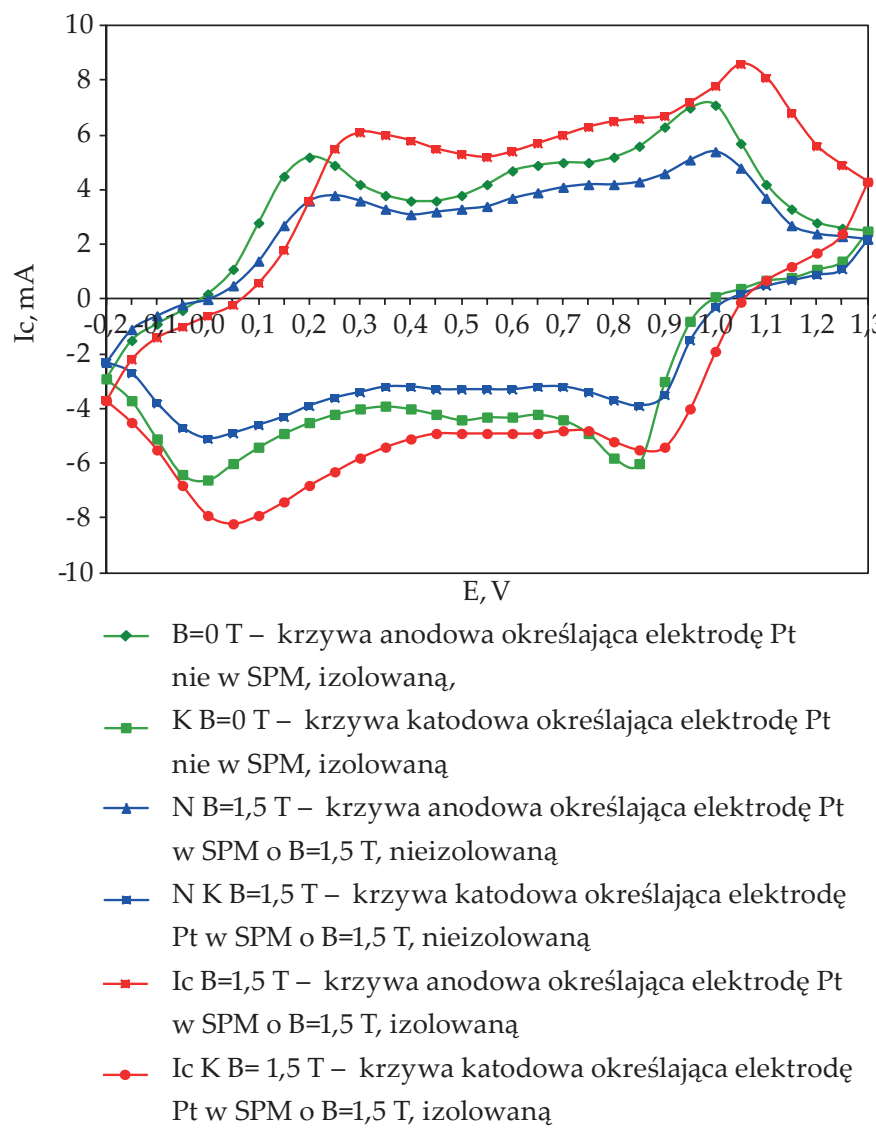

Rys. 4. Woltamperogram polimeryzacji aniliny $\left(0,1 \mathrm{~mol} / \mathrm{dm}^{3}\right)$ w roztworze kwasu chlorowego(VII) $1 \mathrm{~mol} / \mathrm{dm}^{3}$, na platynowej elektrodzie płytkowej, nieizolowanej (N) i izolowanej jednostronnie (Ic) (30 cykli)

Fig. 4. Cyclic voltammogram of aniline $\left(0.1 \mathrm{~mol} / \mathrm{dm}^{3}\right)$ electropolymerization in $1 \mathrm{~mol} / \mathrm{dm}^{3}$ chloric acid(VII) solution, on a platinum plate electrode, non-insulated $(\mathrm{N})$ and one-side insulated (Ic) $(30$ cycles)

ruch obrotowy elektrolitu również sprzyjający ruchowi cząstek w kierunku elektrody.

Następnie zbadano reakcję redukcji w procesie polimeryzacji aniliny z uwzględnieniem dodatnich cząstek paramagnetycznych. Na rys. 3 przedstawiono procentową zależność zmiany natężenia prądu katodowego od indukcji magnetycznej. Największy wpływ siły pochodzącej ze stałego pola magnetycznego (SPM) na dyfuzję jonów w kierunku elektrody zaobserwowano dla wariantu C.

Rysunek 4 przedstawia woltamperogramy (30 cykli) polimeryzacji aniliny na elektrodzie platynowej o powierzchni nieizolowanej - wariant A (N) i powierzchni izolowanej jednostronnie teflonem - wariant $C$ (Ic), dla indukcji magnetycznej $B=0$ i B=1500 mT. Największe zmiany natężenia prądu, zarówno dla części anodowej (I B=1,5 T), jak i katodowej (I K B=1,5 T), uzyskano dla elektrody izolowanej teflonem jednostronnie (wariant C), w SPM o wartości indukcji magnetycznej B=1500 mT (1,5 T). Świadczy to o tym, że przy takich parametrach procesu i takim

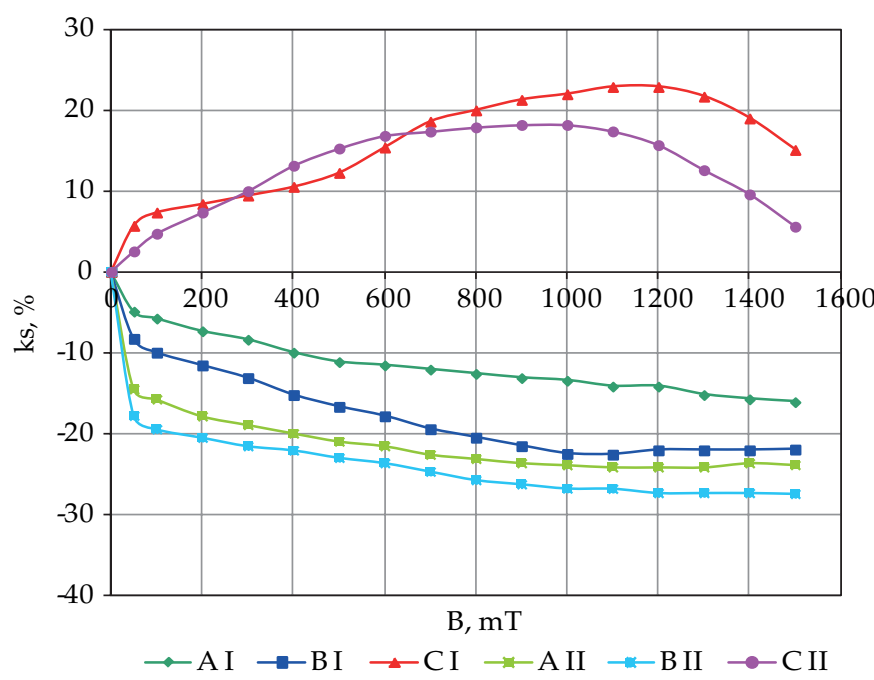

Rys. 5. Zależność zmiany stałej szybkości reakcji $\left(\mathrm{k}_{\mathrm{s}}\right)$ od indukcji magnetycznej (B) w reakcji polimeryzacji aniliny $\left(0,1 \mathrm{~mol} / \mathrm{dm}^{3}\right)$ w roztworze kwasu chlorowego(VII) $1 \mathrm{~mol} / \mathrm{dm}^{3}$, na elektrodzie platynowej, odpowiednio dla dwóch etapów przenoszenia ładunku - I i II

Fig. 5. Dependence of the constant rate change $\left(k_{s}\right)$ on the magnetic induction (B) in the polymerization reaction of aniline $\left(0.1 \mathrm{~mol} / \mathrm{dm}^{3}\right)$ in $1 \mathrm{~mol} / \mathrm{dm}^{3}$ chloric acid(VII) solution, on the platinum electrode, for the two charge-transfer steps - I and II, respectively

ustawieniu elektrod reakcja polimeryzacji aniliny w SPM będzie przebiegała z większą wydajnością.

Rysunek 5 przedstawia procentową zależność zmiany całkowitej stałej szybkości reakcji redoks polimeryzacji aniliny $\left(\mathrm{k}_{\mathrm{s}}\right)$ od indukcji magnetycznej (B). Charakterystyczny jest wzrost wartości $\mathrm{k}_{\mathrm{s}}$ dla wariantu C. Z wykresu łatwo odczytać, że wzrost wartości stałych szybkości reakcji redoks w SPM dla polimeryzacji aniliny wyniósł ok. $30 \%$.

\section{PODSUMOWANIE}

W badaniach elektrochemicznego otrzymywania polianiliny w stałym polu magnetycznym (SPM) funkcje prądu, w zależności od wzrostu indukcji magnetycznej $\mathrm{B}$, miały charakter rosnący lub malejący dla obu badanych układów redoks, w zależności od wariantu położenia powierzchni elektrody (B lub C) względem kierunku i zwrotu wektora B, a także czy elektroda była jednostronnie izolowana teflonem (wariant B lub C) czy nieizolowana (wariant A). Wpływ na oddziaływanie SPM na elektrochemiczne procesy polimeryzacji aniliny miały również właściwości magnetyczne (np. paramagnetyczne, diamagnetyczne) cząstek biorących udział w reakcji elektrochemicznej, a także ich właściwości elektryczne (ładunek +/-). Mechanizm zewnętrznego wpływu SPM na badane reakcje elektrochemiczne przy równoległym kierunku indukcji magnetycznej do powierzchni elektrody polegał na powstawaniu efektu magnetohydrodynamicznego (MHD), czyli zmianie szybkości transportu 
reagujących substancji do elektrody, magnetohydrodynamicznym ruchu elektrolitu i zmianie kinetyki procesów elektrodowych. Zmiany stałych szybkości reakcji elektrochemicznych $\left(\mathrm{k}_{\mathrm{s}}\right)$ na skutek działania zewnętrznego SPM dla procesu polimeryzacji aniliny wynosiły ok. 30\%. Siły magnetyczne Lorentza powodowały ruch fazy ciekłej, który był styczny do powierzchni fazy stałej i prostopadły do kierunku indukcji magnetycznej B. Założono laminarny i jednokierunkowy przepływ fazy ciekłej. Utworzenie warstwy hydrodynamicznej Naviera i Stokesa spowodowało zmniejszenie warstwy dyfuzyjnej Nernsta. Na powierzchni fazy stałej pod wpływem SPM zmniejszyła się grubość warstwy dyfuzyjnej Nernsta. Zmniejszenie grubości warstwy dyfuzyjnej Nernsta w konsekwencji zwiększyło stężenie cząstek aniliny przy fazie stałej, co spowodowało większe osadzanie się cząstek polianiliny. W przypadku stosowania elektrod z obustronną powierzchnią czynną (np. elektroda płytkowa) należało zaizolować jedną stronę powierzchni elektrody, w przeciwnym razie następowało uśrednianie efektów oddziaływania SPM po obu stronach elektrody i w rezultacie brak wpływu SPM na procesy elektrochemicznej polimeryzacji.

\section{LITERATURA}

[1] Miękoś E., Cichomski M., Zieliński M. et al.: Materials 2021, 14 (14), 3806. https://doi.org/10.3390/ma14143806

[2] Miękoś E., Zieliński M., Kołodziejczyk K. et al.: Road Materials and Pavement Design 2019, 20 (2), 440.

[3] Zieliński M., Burnat B., Miękoś E.: ChemistryOpen 2020, 9 (12), 1229. https://doi.org/10.1002/open.202000066

[4] Jaksender M., Miękoś E., Zieliński M. et al.: International Journal of Electrochemical Science 2018, 13, 6897. https://doi.org/10.20964/2018.07.05

[5] Kołodziejczyk K., Miękoś E., Zieliński M. et al.: Journal of Solid State Electrochemistry 2018, 22 (6), 1629. https://doi.org/10.1007/s10008-017-3875-x

[6] Zhang M., Nautiyal A., Du H. et al.: Electrochimica Acta 2021, 376, 138037.

https://doi.org/10.1016/j.electacta.2021.138037

[7] Chowdhury A.D., De A., Chaudhuri C.R. et al.: Sensors and Actuators B: Chemical 2012, 171-172, 916. https://doi.org/10.1016/j.snb.2012.06.004

[8] Dalmolin C., Canobre S.C., Biaggio S.R. et al.: Journal of Electroanalytical Chemistry 2005, 578 (1), 9. https://doi.org/10.1016/j.jelechem.2004.12.011

[9] Korent A., Soderžnik K.Ž., Šturm S. et al.: Journal of The Electrochemical Society 2020, 167 (10), 106504. https://doi.org/10.1149/1945-7111/ab9929

[10] Okamoto H., Ando Y., Kotaka T.: Synthetic Metals 1998, 96(1), 7. https://doi.org/10.1016/s0379-6779(98)00041-1

[11] Mastalerz P.: „Chemia organiczna”, Wydawnictwo Naukowe PWN, Warszawa 1986.

[12] Białecka-Florjańczyk E., Włostowska J.: „Chemia organiczna", WNT, Warszawa 2005.

[13] Łapkowski M.: Wiadomości Chemiczne 1987, 239, 3-4.

[14] Mohilner D.M., Adams P.N., Argenzinger W.I.: Journal of The American Chemical Society 1962, 8, 208.

[15] Łapkowski M.: Synthetic Metals 1990, 35 (1-2), 169. https://doi.org/10.1016/0379-6779(90)90041-I

[16] Genies E.M., Łapkowski M., Penneau J.F.: Journal of Electroanalytical Chemistry 1988, 249, 97.

[17] Galus Z.: „Teoretyczne podstawy elektroanalizy chemicznej", Wydawnictwo Naukowe PWN, Warszawa 1977.

[18] Koryta J., Dvořak J., Bohačkova V.: „Elektrochemia”, Wydawnictwo Naukowe PWN, Warszawa 1980.

Otrzymano 14 VI 2021 r. 